\title{
Confrontos críticos com o imaginário
}

\section{Don Rubin}
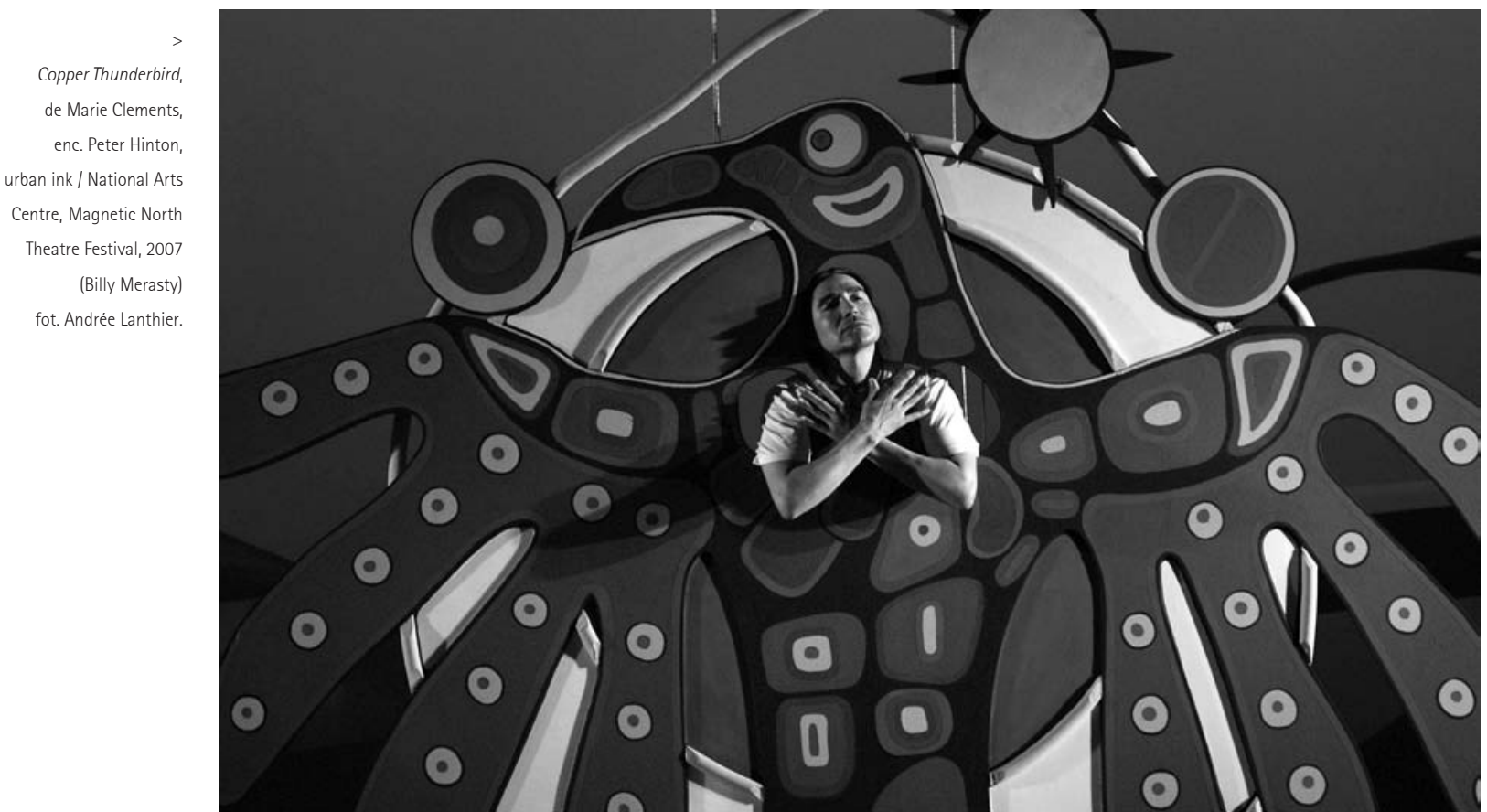

Parece-me que na tradição do teatro ocidental há duas tendências maiores que chegaram até nós e que se relacionam com o tema geral das ficções dramatúrgicas e cenográficas.

A primeira é a que eu chamaria a tradição ditirâmbica, uma tradição de teatro que tem raízes morais, sociais e,

Programa de Pósgraduação em Estudos

$$
\text { de Teatro na }
$$

Universidade de lorque

em Toronto.

É Presidente do Centro

Canadiano da AlCT. obviamente, religiosas. É uma tradição que surge muito cedo pela mão de poetas e sacerdotes envolvendo noções sobre o que seria a vida correcta (com tudo o que de positivo e negativo isso implica), uma tradição cheia de visões e revisões, uma tradição alicerçada, mais do que tudo, no texto e na advertência e repreensão.

A segunda tendência maior tem raizes mais teatrais, está mais ligada ao espectáculo, apela ao aspecto visual, quer deslumbrar, é mais da ordem da representação e da forma do que do conteúdo.

Vistas em conjunto, julgo que é lícito dizer que, em última análise, elas são aspectos complementares do imaginário - uma com uma radicação mais intelectual, outra mais visceral. Como críticos, como é que nos temos confrontado com estas duas tendências no teatro? Como é que nos devemos confrontar?
Vamos recordar um pouco como foi.

Habitualmente consideramos Ésquilo o primeiro dos grandes dramaturgos ocidentais. Nos últimos dois meses tenho andado a trabalhar muito especificamente com a obra de Ésquilo num curso de pós-graduação que cooriento na Universidade de lorque em Toronto. Eu pessoalmente faço incidir o meu trabalho nas peças de Ésquilo, as suas palavras e o seu sentido. Ou seja, as noções ditirâmbicas.

Para dar vida à outra parte da equação - o espectáculo - trouxe para Toronto uma das coreógrafas e encenadoras mais destacadas da Grécia, Regina Kapetenakis, do Teatro Nacional da Grécia. Gina já encenou mais de 120 espectáculos em Atenas, dos quais mais de 20 no grande teatro ao ar livre de Epidauro, com 17000 lugares.

Nas minhas aulas, falei aos estudantes do interesse muito especial de Ésquilo pelas noções de justiça - a relação entre a humanidade e os deuses, o eterno e o efémero desde Prometeu agrilhoado até à Oresteia.

Gina, pelo seu lado, falou aos estudantes das guerras em que Ésquilo participou e do equipamento pesadíssimo usado pelos exércitos atenienses para suster o avanço dos 

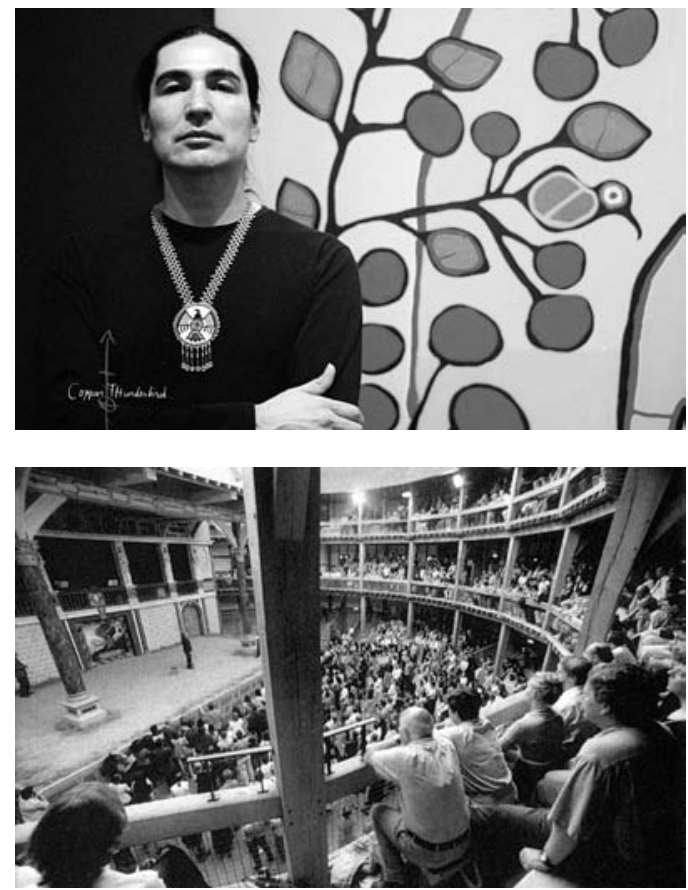

persas pela Europa há 2500 anos. 0 que mais me surpreendeu nas coisas de que Gina falou aos estudantes relativamente a este contexto foi verificar que o público - tanto antigo como moderno - parece ser atraído especialmente para as preocupações de Ésquilo tanto relativamente ao espectáculo como ao texto, a sua vontade de abrir o coro ao movimento nos espaços que eram originalmente da ordem do sagrado e a sua decisão enquanto "encenador" de trazer para o seu teatro algum do equipamento militar que - depois das guerras persas - ficara sem uso, ociosamente abandonado na pacífica Atenas.

Porque Ésquilo dirigia também as suas peças, não tinha que explicar a sua estratégia a mais ninguém senão à loja do exército que the fornecia os materiais. E uma vez explicada essa estratégia, o teatro antigo viu a sua primeira utilização do que acabou por se chamar o deus ex machina - gruas que faziam os deuses entrar voando e máquinas que salvavam personagens reais das suas situações humanas impossiveis fazendo-as voar para fora de cena. Claramente, quando um helicóptero aterrava no palco da comédia musical Miss Saigon há umas quantas temporadas atrás, já se tinha feito um longo caminho desde o primeiro uso da máquina de guerra espectacular no teatro.

Se nós seguirmos o espectáculo ao longo da sua extensa história no teatro, reparamos que a sua popularidade cresceu enormemente em fantasmas e miragens, tremores de terra e nevões, avalanches e vozes de além-túmulo de Shakespeare a Ibsen, de Todo-o-mundo (Everyman') a Gordon Craig. Com certeza que a todos nós já aconteceu em momentos diferentes ao longo dos nossos percursos teatrais que o espectáculo - até mais do que o texto tenha sido de facto o verdadeiro cerne da experiência teatral. Deveríamos nós então, como críticos, olhar mais de perto e com mais atenção para o espectáculo nos nossos teatros modernos? Ainda que seja doloroso admiti-lo, não será que a nossa crítica mais intelectual tem menosprezado a parte espectacular do que todos nós pensamos como sendo o imaginário dramático?

0 que eu estou aqui a sugerir é que talvez alguns de nós, críticos, que damos mais atenção aos textos, devêssemos repensar o nosso posicionamento. A verdade é que captar a tensão naquela zona precisa entre o texto e as manifestações visuais é um desafio cada vez mais difícil. Pensemos em particular no teatro site-specific, seguramente o requinte gastronómico do momento no Canadá e em muitos paises, e o desafio crítico torna-se ainda mais exigente.

E não é só no Canadá. No ano passado, passei seis meses na África do Sul e vi por lá inúmeros exemplos de trabalhos site-specific. Um espectáculo sobre a Grande Viagem dos Boers através da ponta sul do continente quando eles procuravam a terra prometida pela qual não precisassem de lutar - foi realizado numa enorme pista circular de corridas. Mais tarde vi a versão do mito de Orfeu na criação do encenador Brett Bailey num festival de arte internacional na região do vinho Spier perto de Stellenbosch. Essa produção foi montada à beira de um pequeno lago e num bosque escuro no interior da região. Nós, como público, marchávamos conscienciosamente de cena para cena (conduzidos por um actor negro, pequeno mas forte, que aos berros nos ia dando ordens), passando da música à beira da água para o mundo escuro, crestado, na escuridão profunda da selva seguindo o enlouquecido Orfeu na sua procura site-specific.

Recentemente no Canadá, vi dois espectáculos no Festival Magnetic North do novo teatro em Ottawa. Um deles passava-se mesmo num palco (que original!) no
Copper Thunderbird, de Marie Clements, enc. Peter Hinton, urban ink / National Arts Centre, Magnetic North Theatre Festival, 2007 (o actor Billy Merasty em frente a Observations of the Astral World, de Norval Morriseau), fot. Andrée Lanthier.

0 público no novo Teatro do Globo de Shakespeare, na temporada de 1996, fot. John Tramper. $<$ 


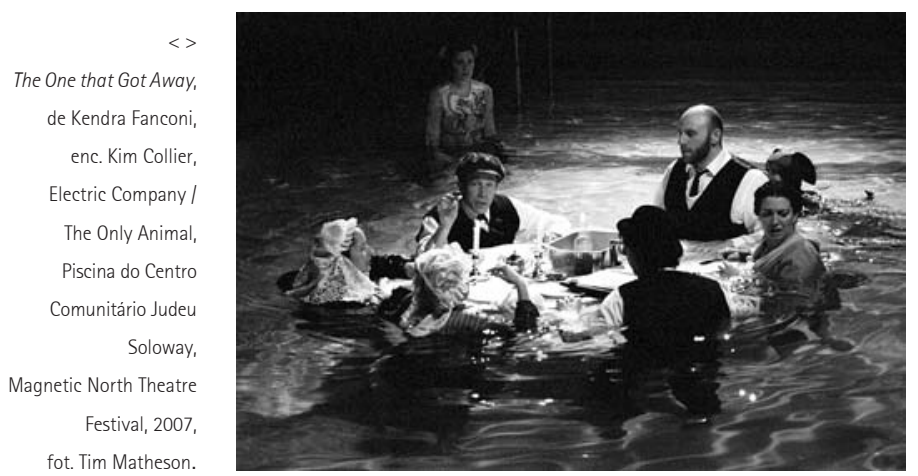

riquissimo Teatro do Centro Nacional das Artes. Trabalhando em torno do grande pintor nacional Norval Morrisseau, 0 espectáculo era mais sobre as suas visões espectaculares traduzidas em cores e formas. Era, de facto, menos uma peça do que um exercício extraordinário de criação de imagens, embora talvez não se tratasse em rigor daquele teatro de imagens a que estávamos habituados.

Duas noites depois no mesmo festival, fui a um espectáculo sobre a vida, a morte e a ressurreição feito numa piscina num Centro Comunitário Judeu. Sim, numa piscina. Uma enorme piscina olímpica. Com um limite de 50 espectadores por sessão, começava num pequeno quarto de hospital onde nos amontoávamos para ver um velho que respirava ofegante, queixava-se e depois morria. Éramos então conduzidos para fora desse espaço minúsculo na direcção da piscina onde a vida inteira do homem era apresentada desde o nascimento até à ressurreição - tudo na água - e onde os actores nadavam na direcção de uma placa flutuante discutindo questões de negócios, para uma outra zona da piscina onde se faziam as cerimónias de purificação ritual, e mais tarde para o céu (na zona mais longínqua da piscina) onde se recordava o holocausto. De forma bem comportada olhávamos para os actores que saíam da piscina a escorrer água e se dirigiam para a plataforma de vidro flutuante subindo cada vez mais até chegarem aos vestiários do terceiro andar onde abriam os braços e se deixavam cair no céu dos nadadores "tespianos".

0 problema para mim com todos estes recentes espectáculos site-specificé que na sua maioria são de uma grande pobreza de escrita. Como esta moda de sitespecificity tem vindo a dominar a equação artística e intelectual, o lado de ideias do teatro, o lado ditirâmbico do teatro enfraqueceu muito consideravelmente. Ponham estas mesmas peças em palcos mais tradicionais e eu ouso afiançar que de imediato se constataria o seu carácter fraquissimo, a imaturidade da escrita, a falta de arte e de sentido da história propriamente dita. 0 que parece encantador e algo comovente numa piscina ficaria muito provavelmente destituido de qualquer significado em terra firme. Quando todo o fumo e brilho enfraquecerem, o que parece engraçado numa pista de corridas ou perto de um lago numa tarde abafada de África pode ser simplesmente enervante quando examinado de forma mais sóbria.

Suponho que é por isso que continuamente voltamos ao génio dos gregos e do drama isabelino e de dramaturgos como Ésquilo e Shakespeare. Os efeitos e o espectáculo de

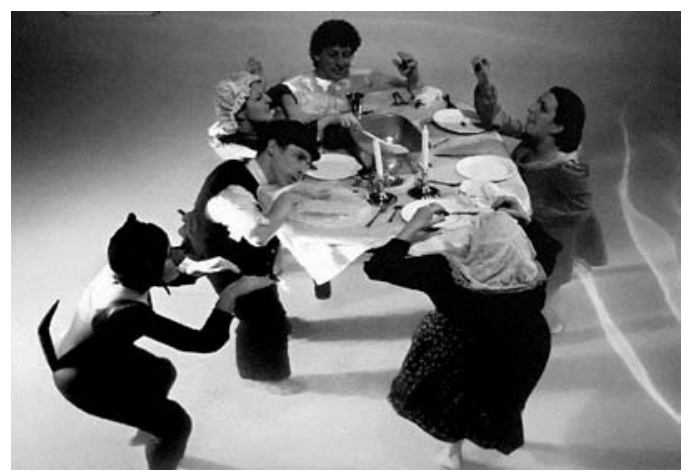

Ésquilo não eram uma alternativa, antes estavam intrinsecamente ligados à poesia sublime que acompanhava a magia das danças corais espectaculares e os mistérios das máquinas. 0 Teatro do Globo de Shakespeare - como - Globo reconstruído nos mostra claramente em Londres - permitia que o espectáculo fluisse por entre os espectadores de uma forma que as produções shakespearianas mais tradicionais não conseguem recuperar, mas que pode ser visto e sentido por um momento nos confins desse Globo facsimilado.

Perece-me que o que nos falta hoje é esse equilibrio mágico entre os aspectos visual e textual no teatro, entre o espectacular e o ditirâmbico. 0 que vemos cada vez mais é o domínio do visual quer em palcos tradicionais de teatros comerciais, quer em trabalhos de site-specific em edifícios não convencionais, quer em peças de arte performativa em galerias.

Eu, como crítico, preciso do equilíbrio entre grandes ideias - poesia, boa escrita numa modalidade qualquer e grandes elementos de representação que possam complementar ou mesmo reformular as palavras. Com certeza que, quando se vê esse equilibrio, muitos de nós respondemos de forma imediata e entusiástica - quer seja nos espectáculos do encenador letão Alvis Hermanis, em alguns dos melhores trabalhos do encenador canadiano Robert Lepage, no trabalho de Peter Brook desde Marat / Sade, passando por Iks, nas poderosas fantasias políticas de Ariane Mnouchkine.

Falando em meu nome pessoal, estou ansiosamente à espera dos grandes mestres do novo palco deste próximo milénio, aqueles que serão suficientemente ousados para encontrar de novo aquele equilibrio delicado entre a poesia e o espectáculo, aqueles que, depois de muito esperarmos, consigam de novo vivificar o que é hoje um teatro mundial bastante indiferenciado, um teatro onde encenadores e cenógrafos parecem bater-se com escritores pela supremacia e onde já não aparece o antigo casamento da forma e do conteúdo. Chamem-me homem de Neanderthal se quiserem, mas eu espero ansiosamente por um teatro onde o espectáculo - em toda a sua fúria imaginativa for uma vez mais verdadeiramente celebrado como um companheiro essencial pelo reduto visionário da maquinação mais puramente teatral das coisas imaginadas - o escritor.

Tradução de Maria Helena Serôdio 